\title{
Efisiensi Rantai Pasok pada Makanan Tidak Tahan Lama Berdasarkan Permintaan Stokastik dan Densitas Bersyarat
}

\author{
Nur Holisah", a), Sudarwanto ${ }^{1, \text { b) }}$, Ibnu Hadi ${ }^{1, ~ c)}$ \\ ${ }^{1}$ Program Studi Matematika, Fakultas Matematika dan Ilmu Pengetahuan Alam, Universitas Negeri Jakarta \\ Jalan Rawamangun Muka, Rawamangun, Jakarta Timur, Jakarta
}

Email: ${ }^{\text {a) }}$ nurholisah042@gmail.com, ${ }^{\text {b) }}$ sudarwanto@fmipa.unj.ac.id , ${ }^{c}$ ibnuhadi@fmipa.unj.ac.id

\begin{abstract}
Supply chain for perishable food is managed independently to maximize the profit. The possible spoilage of the perishable food due to its deterioration nature and the retail demand uncertainty result in a challenging task to manage perishable food supply chains. So, the pricing strategy is used in order to all items can be sold out before their expired date. The strategy of determining price and discount, also restock policy can be approached by stochastic demand in the single item perishable food supply chain. Meanwhile the strategy of determining shelf space can be approached by the conditional density in multiitem perishable food supply chain.
\end{abstract}

Keywords: supply chain, perishable food, stochastic demand, conditional density

\begin{abstract}
Abstrak
Rantai pasok pada makanan tidak tahan lama dikelola secara independen untuk memaksimalkan keuntungan. Makanan yang mudah kedaluwarsa dan ketidakpastian permintaan konsumen membuat rantai pasok pada makanan tidak tahan lama sulit dikelola. Akibatnya diberikan diskon sebagai strategi untuk makanan dapat laku terjual sebelum kedaluwarsa. Strategi penentuan harga dan diskon, serta kebijakan stok dapat didekati dengan permintaan stokastik dalam model satu jenis makanan tidak tahan lama. Selain itu, strategi penentuan besarnya rak dapat didekati dengan densitas bersyarat untuk model beragam jenis makanan tidak tahan lama.
\end{abstract}

Kata-kata kunci: rantai pasok, makanan tidak tahan lama, permintaan stokastik, densitas bersyarat

\section{PENDAHULUAN}

Pembelian jenis makanan tidak tahan lama sudah menjadi hal umum di masyarakat. Tingginya permintaan konsumen terhadap jenis makanan tidak tahan lama membawa dampak positif bagi pengusaha industri makanan. Salah satunya adalah menambah pendapatan pengusaha industri makanan.

Makanan yang tidak laku terjual atau kedaluwarsa akan menjadi sampah yang harus dibuang. Pembuangan sampah dapat menimbulkan biaya pembuangan di toko. Selain menimbulkan biaya pembuangan, sampah tersebut menjadi limbah yang berdampak negatif bagi lingkungan, seperti kerusakan lingkungan. Biaya pembuangan dan kerusakan lingkungan dapat mengakibatkan kerugian bagi pengusaha industri makanan.

Kerugian yang dialami dalam penjualan jenis makanan tidak tahan lama, mengakibatkan pengusaha industri makanan memiliki tantangan yang sulit dalam memanajemen rantai pasok makanan. 
Bukeviciute (2009) menjelaskan bahwa manajemen rantai pasok makanan tidak tahan lama merupakan suatu manajemen dari aliran barang, informasi dan dana melalui aktivitas yang saling terkait untuk menghubungkan antara pemasok, perusahaan manufaktur, gudang, jasa transportasi, ritel dan konsumen secara efisien. Pada manajemen rantai pasok makanan tidak tahan lama, barang yang diproduksi dan didistribusi memiliki kualitas, lokasi dan waktu yang tepat untuk memaksimalkan keuntungan dan memuaskan tingkat pelayanan.

Menurut Xiao (2016) dan Yang (2017) strategi penentuan harga dan diskon bergantung terhadap penurunan kualitas makanan. Akibatnya, penentuan harga dan diskon memegang peranan penting dalam penjualan terutama saat makanan mendekati tanggal kedaluwarsa. Selain kualitas dan harga, besarnya rak merupakan faktor yang mempengaruhi tingkat pembelian konsumen, karena rak yang lebih besar untuk memajang produk dapat membuat produk lebih mudah terlihat, serta dapat meningkatkan daya beli.

Kebijakan stok dalam rantai pasok makanan tidak tahan lama merupakan faktor yang dapat memuaskan tingkat pelayanan di toko. Stok yang selalu tersedia dapat mengatasi kehabisan produk di toko. Kebijakan stok yang tepat dapat menambah pelanggan dan meningkatkan pendapatan di toko.

Strategi penentuan harga dan diskon, besarnya ruangan untuk rak, serta kebijakan stok merupakan faktor utama yang dapat memaksimalkan keuntungan pada rantai pasok makanan tidak tahan lama. Efisiensi adalah kegiatan memaksimalkan keuntungan dengan menekan biaya-biaya yang ada di toko. Dalam efisiensi rantai pasok makanan tidak tahan lama, penyelesaian model satu jenis dengan permintaan stokastik, permintaan konsumen untuk model beragam jenis makanan tidak tahan lama diasumsikan secara tidak independen dan diselesaikan melalui densitas bersyarat. Densitas bersyarat merupakan permintaan konsumen untuk model beragam jenis (terdiri dari sayuran, daging, buahbuahan, seafood, ikan air tawar, telur, dan susu) yang saling bergantung terhadap permintaan konsumen sayuran, dengan kondisi bahwa permintaan konsumen sayuran berasal dari model satu jenis. Berdasarkan uraian di atas, maka akan dilakukan penelitian mengenai efisiensi rantai pasok pada makanan tidak tahan lama berdasarkan permintaan stokastik dan densitas bersyarat.

\section{PEMBAHASAN}

\section{Penurunan Kualitas Makanan Tidak Tahan Lama}

Menurut B. Ling (2015), penurunan kualitas dari makanan tidak tahan lama dipengaruhi berbagai faktor, di antaranya waktu penyimpanan, suhu dan kondisi atmosfer, dan dapat dirumuskan sebagai berikut:

$$
\frac{d q}{d t}=-k_{0} e^{-\frac{E_{a}}{R T_{0}}} q^{n}
$$

Di mana, $(q)$ merupakan kualitas makanan, $(\lambda)$ merupakan tingkat penurunan kualitas makanan, $(n)$ merupakan order kimiawi dari reaksi penurunan kualitas makanan, $\left(k_{0}\right)$ merupakan konstanta awal, $(E a)$ merupakan energi aktivasi, $(R)$ merupakan konstanta gas, dan $\left(T_{0}\right)$ merupakan temperatur mutlak. Jika $\lambda=k_{0} e^{-\frac{E_{a}}{R T_{0}}}$ maka

$$
\frac{d q}{d t}=-\lambda q^{n}
$$

Xiao (2016) dan Yang (2017) menjelaskan bahwa order kimiawi dari reaksi makanan tidak tahan lama adalah $n=0$ atau $n=1$. Hal itu dikarenakan order kimiawi sangat bergantung pada proses penurunan kualitas makanan. Sebagian besar dari makanan tidak tahan lama seperti sayur, buah, sea food dan daging menurun kualitasnya secara eksponensial di dalam kehidupan nyata. Oleh karena itu dipilih order kimiawi $n=1$. Berdasarkan persamaan (1), penurunan kualitas makanan tidak tahan lama pada waktu $t$ dapat ditulis sebagai berikut:

$$
q(t)=q_{0} e^{-\lambda t}
$$


Efisiensi Rantai Pasok pada Makanan Tidak Tahan Lama Berdasarkan Permintaan Stokastik dan Densitas ...

dengan $(t)$ sebagai periode waktu penyimpanan makanan di toko (jam).

\section{Model Permintaan Konsumen}

Berdasarkan Persamaan (2) permintaan konsumen di rak tidak diskon adalah sebagai berikut:

$$
d_{1}(t)=a-b p+c n_{g}+d q(t)+r q(t) s+\varepsilon
$$

dimana, (a) merupakan skala pasar (range harga), (b) merupakan konstanta dari elastisitas harga makanan tidak tahan lama dengan harga termurah, $(p)$ merupakan harga jual, $(c)$ merupakan konstanta besarnya rak, $\left(n_{g}\right)$ merupakan besarnya rak, $(d)$ merupakan konstanta dari pertimbangan konsumen terhadap penurunan kualitas makanan, $(r)$ merupakan konstanta stok terhadap penurunan kualitas makanan, (s) merupakan banyaknya stok, dan $(\varepsilon)$ merupakan peubah acak dari permintaan konsumen yang bersifat stokastik yang berdistribusi $\operatorname{UNIF}[-L ; L]$, dengan $(L)$ sebagai ketidakpastian dari permintaan konsumen terhadap makanan tidak tahan lama.

Seiring berjalannya waktu, makanan tidak tahan lama mengalami kedaluwarsa. Selain itu, sisa umur simpan makanan tidak tahan lama akan berakhir dan tingkat permintaan konsumen terhadap jenis makanan ini mengalami penurunan. Akibatnya, pengusaha industri makanan menawarkan diskon untuk produk makanan tidak tahan lama, dengan memindahkan makanan di rak tidak diskon ke rak diskon. Permintaan konsumen di rak diskon, yaitu

$$
d_{1}(t)=a-b \Theta p+c n_{g}+d q(t)+r q(t) s+\varepsilon
$$

dimana, $(\Theta)$ merupakan tingkat diskon dengan diskon didefinisikan sebagai $\theta=1-\Theta$, dan $(h)$ merupakan tingkat seberapa tertariknya konsumen membeli makanan tidak tahan lama dalam rak diskon.

Misalkan $\left(t_{0}\right)$ merupakan waktu penjualan makanan tidak tahan lama di rak tidak diskon dan $(T)$ merupakan waktu keseluruhan penjualan makanan tidak tahan lama di rak tidak diskon dan rak diskon. Berdasarkan Persamaan (3) dan Persamaan (4), permintaan konsumen dapat ditulis sebagai berikut:

$$
d(t)= \begin{cases}d_{1}(t), & 0 \leq t \leq t_{0} \\ d_{2}(t), & t_{0} \leq t \leq T\end{cases}
$$

Total permintaan konsumen di rak tidak diskon adalah

$$
\int_{0}^{t_{0}} d_{1}(t) d t=\left(a+c n_{g}\right) t_{0}-b p t_{0}+d q_{0}\left(\frac{1-e^{-\lambda t_{0}}}{\lambda}\right)+r s q_{0}\left(\frac{1-e^{-\lambda t_{0}}}{\lambda}\right)+\varepsilon t_{0}
$$

dimana, $\left(\varepsilon t_{0}\right)$ merupakan permintaan stokastik. Total permintaan konsumen di rak diskon adalah

$$
\int_{t_{0}}^{T} d_{2}(t) d t=(a+h)\left(T-t_{0}\right)-b \Theta p\left(T-t_{0}\right)+d q_{0}\left(\frac{e^{-\lambda t_{0}}-e^{\lambda T}}{\lambda}\right)+r s q_{0}\left(\frac{e^{-\lambda t_{0}}-e^{-\lambda T}}{\lambda}\right)+\varepsilon\left(T-t_{0}\right)
$$

dimana, $\left(\varepsilon\left(T-t_{0}\right)\right)$ merupakan permintaan stokastik.

Misalkan $D_{1}$ dan $D_{2}$ mewakili permintaan konsumen yang diharapkan oleh pengusaha di rak tidak diskon dan rak diskon. Maka

$$
\begin{gathered}
D_{1}=a t_{0}-b p t_{0}+c n_{g} t_{0}+d q_{0}\left(\frac{1-e^{-\lambda t_{0}}}{\lambda}\right)+r s q_{0}\left(\frac{1-e^{-\lambda t_{0}}}{\lambda}\right) \\
D_{2}=(a+h)\left(T-t_{0}\right)-b \Theta p\left(T-t_{0}\right)+d q_{0}\left(\frac{e^{-\lambda t_{0}}-e^{\lambda T}}{\lambda}\right)+r s q_{0}\left(\frac{e^{-\lambda t_{0}}-e^{-\lambda T}}{\lambda}\right)
\end{gathered}
$$

dengan permintaan konsumen yang bersifat stokastik berdasarkan Persamaan (5) dan Persamaan (6), sebagai berikut: 


$$
\frac{1}{2 L T} \int_{0}^{L T-Q+D_{1}+D_{2}} \varepsilon T d \varepsilon t+\frac{1}{2 L T} \int_{0}^{L T+Q-D_{1}-D_{2}} \varepsilon T d \varepsilon t
$$

dimana $(\mathrm{Q})$ merupakan jumlah pembelian makanan tidak tahan lama pada grosir.

\section{Pemodelan Rantai Pasok pada Makanan Tidak Tahan Lama}

Penghasilan dari penjualan jenis makanan tidak tahan lama selama di rak tidak diskon adalah

$$
E\left[\int_{0}^{t_{0}} d_{1}(t) d t\right]=\left(a p+c n_{g} p\right) t_{0}-b p^{2} t_{0}+d q_{0} p\left(\frac{1-e^{-\lambda t_{0}}}{\lambda}\right)+r s q_{0} p\left(\frac{1-e^{-\lambda t_{0}}}{\lambda}\right)+\varepsilon t_{0}
$$

Rak $\left(n_{g}\right)$ yang digunakan untuk memajang produk penjualan makanan tidak tahan lama memiliki biaya pembelian rak $(m)$. Rak digunakan mulai dari awal penjualan pertama makanan sampai waktu makanan tidak tahan lama dijual di rak tidak diskon $\left(t_{0}\right)$. Total biaya pembelian rak $\left(C_{t}\right)$ didefinisikan sebagai $t_{0} m n_{g}{ }^{2}$, dengan $(m)$ biaya pembelian rak per item. Penghasilan yang berasal dari penjualan makanan tidak tahan lama di rak diskon adalah

$$
\begin{gathered}
E\left[p \Theta \int_{0}^{t_{0}} d_{2}(t) d t\right]=(a p \Theta+h p \Theta)\left(T-t_{0}\right)-b \Theta^{2} p^{2}\left(T-t_{0}\right)+d q_{0} p \Theta\left(\frac{e^{-\lambda t_{0}}-e^{\lambda T}}{\lambda}\right)+ \\
r s q_{0} p \Theta\left(\frac{e^{-\lambda t_{0}-e^{-\lambda T}}}{\lambda}\right)
\end{gathered}
$$

Jumlah pembelian makanan tidak tahan lama di grosir $(Q)$ memiliki biaya transportasi atau biaya angkut makanan dari grosir sampai ke toko. Total biaya angkut atau biaya transportasi pembelian makanan $\left(C_{t}\right)$ didefinisikan sebagai $C_{0}\left(Q+s^{2}\right)$, dengan $\left(C_{0}\right)$ sebagai biaya angkut atau biaya transportasi per item. Selain memiliki biaya transportasi, terdapat biaya kekurangan untuk persediaan stok (Stock cost) sebagai biaya yang timbul akibat tidak tersedianya barang stok pada waktu yang diperlukan (Bukeviciute, 2009). Permintaan konsumen yang bersifat stokastik dapat mempertimbangkan biaya kekurangan untuk persediaan stok. Total biaya kekurangan untuk persediaan stok yang diharapkan dengan menggunakan bagian pertama Persamaan (9), yaitu

$$
E\left[C_{S} \frac{1}{2 L T} \int_{0}^{L T-Q+D_{1}+D_{2}} \varepsilon T d \varepsilon t\right]=\frac{C_{S}}{4 L T}\left(L T-Q+D_{1}+D_{2}\right)^{2}
$$

dimana $\left(C_{s}\right)$ merupakan suatu konstanta yang menyatakan biaya kekurangan untuk persediaan stok per item.

Terakhir, terdapat sejumlah produk makanan tidak tahan lama yang tidak laku terjual di akhir umur simpan makanan (kedaluwarsa). Sisa makanan tidak tahan lama yang kedaluwarsa dan tidak laku terjual menjadi sampah yang harus dibuang. Proses pembuangan sampah dapat menyebabkan emisi karbon (karbon dioksida) dan dapat menyebabkan polusi terhadap lingkungan, serta pengusaha harus mengeluarkan biaya pembuangan sampah. Total biaya pembuangan sampah yang diharapkan dengan menggunakan bagian kedua Persamaan (9), yaitu

$$
E\left[C_{d} \frac{1}{2 L T} \int_{0}^{L T-Q+D_{1}+D_{2}} \varepsilon T d \varepsilon t\right]=\frac{C_{d}}{4 L T}\left(L T+Q-D_{1}-D_{2}\right)^{2}
$$

dimana, $\left(C_{d}\right)$ merupakan total biaya pembuangan sampah.

Secara singkat, total keuntungan yang diharapkan pengusaha dalam rantai pasok makanan tidak tahan lama adalah

$$
\begin{array}{r}
E(\pi)=E\left[p \int_{0}^{t_{0}} d_{1}(t) d t\right]+E\left[p \Theta \int_{0}^{t_{0}} d_{2}(t) d t\right]-C_{r}-C_{t} \\
-E\left[C_{s} \frac{1}{2 L T} \int_{0}^{L T-Q+D_{1}+D_{2}} \varepsilon T d \varepsilon T\right]-E\left[C_{d} \frac{1}{2 L T} \int_{0}^{L T+Q-D_{1}-D_{2}} \varepsilon T d \varepsilon T\right]
\end{array}
$$


Efisiensi Rantai Pasok pada Makanan Tidak Tahan Lama Berdasarkan Permintaan Stokastik dan Densitas ...

\section{Optimasi Model Satu Jenis}

Derivatif parsial orde pertama dan kedua keuntungan maksimal $E(\pi)$ terhadap $(p)$ adalah

$$
\begin{gathered}
\frac{\partial E(\pi)}{\partial p}=\left(a p+c n_{g}\right) t_{0}-2 b p t_{0}+d q_{0}\left(\frac{1-e^{-\lambda t_{0}}}{\lambda}\right)+r s q_{0}\left(\frac{1-e^{-\lambda t_{0}}}{\lambda}\right) \\
+(a \Theta+h \Theta)\left(T-t_{0}\right)-2 b \Theta^{2} p\left(T-t_{0}\right) \\
+d q_{0} \Theta\left(\frac{e^{-\lambda t_{0}}-e^{\lambda T}}{\lambda}\right)+r s q_{0}\left(\frac{e^{-\lambda t_{0}}-e^{-\lambda T}}{\lambda}\right) \\
-\frac{C_{s}}{2 L T}\left(-b t_{0}-b \Theta\left(T-t_{0}\right)\right)\left(L T-Q+D_{1}+D_{2}\right) \\
-\frac{C_{d}}{2 L T}\left(b t_{0}-b \Theta\left(T-t_{0}\right)\right)\left(L T+Q-D_{1}-D_{2}\right) \\
\begin{array}{c}
\frac{\partial^{2} E(\pi)}{\partial p^{2}}=-2 b t_{0}-2 b \Theta^{2}\left(T-t_{0}\right)-\frac{C_{S}}{2 L T}\left(-b t_{0}-b \Theta\left(T-t_{0}\right)\right)^{2} \\
-\frac{c_{d}}{2 L T}\left(b t_{0}-b \Theta\left(T-t_{0}\right)\right)^{2}, \quad \operatorname{dimana} \mathrm{T}>\mathrm{t}_{0}
\end{array}
\end{gathered}
$$

Persamaan (16) menunjukan bahwa fungsi $E(\pi)$ cekung bawah di titik $(p)$ dan $(\Theta)$, artinya total keuntungan mencapai maksimal pada harga dan diskon yang telah ditetapkan.

Misalkan keuntungan maksimal $E(\pi)$ dalam rantai pasok pada makanan tidak tahan lama dipengaruhi oleh tiga kendala, seperti jumlah pembelian makanan tidak tahan lama di grosir $(Q)$, besar ruangan untuk rak $\left(n_{g}\right)$ dan jumlah stok $(s)$. Fungsi $E(\pi)$ akan diuji dengan syarat maksimal orde kedua sebagai berikut

$$
\begin{gathered}
\frac{\partial^{2} E(\pi)}{\partial Q^{2}}=-\frac{C_{S}}{2 L T}-\frac{C_{d}}{2 L T}<0 \\
\frac{\partial^{2} E(\pi)}{\partial n_{g}{ }^{2}}=-2 t_{0} m-\frac{C_{s} c^{2} t_{0}{ }^{2}}{2 L T}-\frac{C_{d} c^{2} t_{0}{ }^{2}}{2 L T}<0 \\
\frac{\partial^{2} E(\pi)}{\partial s^{2}}=-2 C_{0}-\frac{C_{s}}{2 L T}\left(r q_{0}\left(\frac{1-e^{-\lambda t_{0}}}{\lambda}\right)+r q_{0}\left(\frac{e^{-\lambda t_{0}}-e^{-\lambda T}}{\lambda}\right)\right)^{2} \\
-\frac{C_{d}}{2 L T}\left(-r q_{0}\left(\frac{1-e^{-\lambda t_{0}}}{\lambda}\right)-r q_{0}\left(\frac{e^{-\lambda t_{0}}-e^{-\lambda T}}{\lambda}\right)\right)^{2}<0
\end{gathered}
$$

Syarat perlu untuk memaksimalkan $E(\pi)$, yaitu $\frac{\partial E(\pi)}{\partial Q}=\frac{\partial E(\pi)}{\partial n_{g}}=\frac{\partial E(\pi)}{\partial s}=0$. Matriks simetri Hessian dari $E(\pi)$ adalah

$$
H=\left|\begin{array}{lll}
\frac{\partial^{2} E(\pi)}{\partial Q^{2}} & \frac{\partial^{2} E(\pi)}{\partial Q \partial n_{g}} & \frac{\partial^{2} E(\pi)}{\partial Q \partial s} \\
\frac{\partial^{2} E(\pi)}{\partial n_{g} \partial Q} & \frac{\partial^{2} E(\pi)}{\partial n_{g}{ }^{2}} & \frac{\partial^{2} E(\pi)}{\partial n_{g} \partial s} \\
\frac{\partial^{2} E(\pi)}{\partial s \partial Q} & \frac{\partial^{2} E(\pi)}{\partial s \partial Q} & \frac{\partial^{2} E(\pi)}{\partial s^{2}}
\end{array}\right|
$$

Dalam Persamaan (20), terdapat

$$
\begin{gathered}
\frac{\partial^{2} E(\pi)}{\partial Q^{2}}=\frac{C_{s} c t_{0}}{2 L T}+\frac{C_{d} c t_{0}}{2 L T} \\
\frac{\partial^{2} E(\pi)}{\partial Q \partial s}=\frac{C_{S}}{2 L T}\left(r q_{0}\left(\frac{1-e^{-\lambda t_{0}}}{\lambda}\right)+r q_{0}\left(\frac{e^{-\lambda t_{0}}-e^{-\lambda T}}{\lambda}\right)\right)
\end{gathered}
$$




$$
\begin{aligned}
& -\frac{c_{d} c t_{0}}{2 L T}\left(-r q_{0}\left(\frac{1-e^{-\lambda t_{0}}}{\lambda}\right)-r q_{0}\left(\frac{e^{-\lambda t_{0}}-e^{-\lambda T}}{\lambda}\right)\right) \\
\frac{\partial^{2} E(\pi)}{\partial n_{g} \partial s}=- & \frac{C_{s} c t_{0}}{2 L T}\left(r q_{0}\left(\frac{1-e^{-\lambda t_{0}}}{\lambda}\right)+r q_{0}\left(\frac{e^{-\lambda t_{0}}-e^{-\lambda T}}{\lambda}\right)\right) \\
& +\frac{C_{d} c t_{0}}{2 L T}\left(-r q_{0}\left(\frac{1-e^{-\lambda t_{0}}}{\lambda}\right)-r q_{0}\left(\frac{e^{-\lambda t_{0}}-e^{-\lambda T}}{\lambda}\right)\right)
\end{aligned}
$$

sehingga

\begin{tabular}{|c|c|}
\hline & $\begin{array}{c}\text { ALGORITMA 1 } \\
\text { Solusi Metodologi Model Satu Jenis }\end{array}$ \\
\hline Langkah 1: & $\begin{array}{l}\text { Lakukan } E(\pi)_{o p t}=0, C_{0}=p, Q=0, n_{g}=0 \text { dan } s=0 \text { untuk } \\
\text { memperoleh nilai } C_{0} \text {. }\end{array}$ \\
\hline Langkah 2: & $\begin{array}{l}\text { Lakukan } p^{*}=p+0.01 \text {, di mana } E(\pi)^{*}, Q^{*}, n_{g}^{*} \text { dan } s^{*} \text { dapat } \\
\text { diperoleh dari Persamaan } \frac{\partial E(\pi)}{\partial Q}=\frac{\partial E(\pi)}{\partial n_{g}}=\frac{\partial E(\pi)}{\partial s}=0 .\end{array}$ \\
\hline Langkah 3: & $\begin{array}{l}\text { Jika } E(\pi)^{*}>E(\pi)_{\text {opt }} \text { maka perbaharui nilai } E(\pi)_{\text {opt }}, Q^{*}, n_{g}^{*} \text { dan } \\
s^{*} \text { yang diperoleh pada Langkah } 2 \text {. Jika } E(\pi)^{*}<E(\pi)_{\text {opt }} \text { maka } \\
E(\pi)_{\text {opt }}, Q^{*}, n_{g}^{*} \text { dan } s^{*} \text { merupakan solusi optimal. }\end{array}$ \\
\hline
\end{tabular}

$$
H=-2 t_{0} m C_{0}\left(\frac{C_{s}+C_{d}}{L T}\right)<0
$$

Fungsi $E(\pi)$ maksimal dengan kendala $\left(Q^{*}\right), n_{g}{ }^{*}$ dan $s^{*}$.

Gambar 1. Algoritma 1

Algoritma 1 merupakan solusi metodologi untuk menyelesaikan simulasi numerik makanan tidak tahan lama satu jenis pada subbab selanjutnya.

\section{Model Beragam Jenis untuk Rantai Pasok Makanan Tidak Tahan Lama}

Misalkan permintaan konsumen terhadap sayuran sama dengan permintaan konsumen dalam model satu jenis, yaitu $\left(D_{1}\right)$ merupakan permintaan konsumen terhadap sayuran di rak tidak diskon dan $\left(D_{2}\right)$ permintaan konsumen terhadap sayuran di rak diskon. Model permintaan konsumen beragam jenis makanan tidak tahan lama di rak tidak diskon dan rak diskon dapat ditulis sebagai berikut:

$$
D_{b j}= \begin{cases}D_{1} D_{d g} D_{b} D_{s f} D_{i t} D_{t l} D_{s s}, & 0 \leq D_{1} \leq t_{0} \\ D_{2} D_{d g} D_{b} D_{s f} D_{i t} D_{t l} D_{s s}, & t_{0} \leq D_{1} \leq T\end{cases}
$$

dimana $\left(D_{\mathrm{dg}}\right)$ merupakan permintaan konsumen terhadap daging, $\left(D_{b}\right)$ merupakan permintaan konsumen terhadap buah-buahan, $\left(D_{\text {sf }}\right)$ merupakan permintaan konsumen terhadap sea food, $\left(D_{i t}\right)$ merupakan permintaan konsumen terhadap ikan air tawar, $\left(D_{t l}\right)$ merupakan permintaan konsumen terhadap telur, $\left(D_{\mathrm{ss}}\right)$ merupakan permintaan konsumen terhadap susu.

Permintaan konsumen yang saling bergantung dapat diselesaikan dengan menggunakan fungsi densitas bersyarat. Berdasarkan Persamaan (24), total permintaan konsuman beragam jenis makanan tidak tahan lama, dengan permintaan konsumen terhadap sayuran yang bergantung pada permintaan konsumen terhadap daging, buah-buahan, sea food, ikan air tawar, telur dan susu di rak tidak diskon, adalah

$$
f\left(D_{1} \mid D_{d g}, D_{b}, D_{s f}, D_{i t}, D_{t l}, D_{s s}\right)=\frac{2}{{t_{0}}^{2}}\left(a t_{0}-b p t_{0}+c n_{g} t_{0}+d q_{0}\left(\frac{1-e^{-\lambda t_{0}}}{\lambda}\right)+r s q_{0}\left(\frac{1-e^{-\lambda t_{0}}}{\lambda}\right)\right)
$$

Penghasilan yang diharapkan pengusaha dari penjualan beragam jenis makanan tidak tahan lama di rak tidak diskon adalah 
Efisiensi Rantai Pasok pada Makanan Tidak Tahan Lama Berdasarkan Permintaan Stokastik dan Densitas ...

$$
\begin{gathered}
E\left[p f\left(D_{1} \mid D_{d g}, D_{b}, D_{s f}, D_{i t}, D_{t l}, D_{s S}\right)\right]=\frac{2}{t_{0}^{2}}\left(\left(a p+c n_{g} p\right) t_{0}-b p^{2} t_{0}+d q_{0} p\left(\frac{1-e^{-\lambda t_{0}}}{\lambda}\right)\right. \\
\left.+r s q_{0}\left(\frac{1-e^{-\lambda t_{0}}}{\lambda}\right)\right)
\end{gathered}
$$

Berdasarkan Persamaan (24), total permintaan konsuman beragam jenis makanan tidak tahan lama, dengan permintaan konsumen terhadap sayuran yang bergantung pada permintaan konsumen terhadap daging, buah-buahan, sea food, ikan air tawar, telur dan susu di rak diskon adalah

$$
\begin{gathered}
f\left(D_{2} \mid D_{d g}, D_{b}, D_{s f}, D_{i t}, D_{t l}, D_{s s}\right)=\frac{2}{T^{2}-t_{0}{ }^{2}}\left((a+h)\left(T-t_{0}\right)-b \Theta p\left(T-t_{0}\right)\right. \\
\left.+d q_{0}\left(\frac{e^{-\lambda t_{0}-e^{\lambda T}}}{\lambda}\right)+r s q_{0}\left(\frac{e^{-\lambda t_{0}-e^{-\lambda T}}}{\lambda}\right)\right)
\end{gathered}
$$

Penghasilan yang diharapkan pengusaha dari penjualan beragam jenis makanan tidak tahan lama di rak diskon adalah

$$
\begin{gathered}
E\left[p \Theta f\left(D_{2} \mid D_{d g}, D_{b}, D_{s f}, D_{i t}, D_{t l}, D_{s s}\right)\right]=\frac{2 p \Theta}{T^{2}-t_{0}^{2}}\left((a+h)\left(T-t_{0}\right)-b \Theta p\left(T-t_{0}\right)\right. \\
\left.+d q_{0}\left(\frac{e^{-\lambda t_{0}-e^{\lambda T}}}{\lambda}\right)+r s q_{0}\left(\frac{e^{-\lambda t_{0}}-e^{-\lambda T}}{\lambda}\right)\right)
\end{gathered}
$$

Biaya transportasi dari pembelian produk per item dan stok per item pada model beragam jenis $(\mathrm{Cu})$ didefinisikan sebagai $(\alpha s-\beta Q)$ s, dengan $(\alpha)$ sebagai biaya transportasi pembelian stok di grosir dan $(\beta)$ sebagai fluktuasi diskon terhadap kuantitas barang yang dibeli $(Q)$. Selain itu, total biaya pembuangan sampah beragam jenis makanan tidak tahan lama $\left(C_{b}\right)$ pada model beragam jenis, didefinisikan sebagai $(\alpha-\beta Q)\left(D_{1}+D_{2}\right)$.

Secara singkat, total keuntungan dari penjualan beragam jenis makanan tidak tahan lama yang diharapkan pengusaha dalam rantai pasok makanan tidak tahan lama adalah

$$
\begin{aligned}
E(\Pi)= & E\left[p f\left(D_{1} \mid D_{d g}, D_{b}, D_{s f}, D_{i t}, D_{t l}, D_{s s}\right)\right]+E\left[p \Theta f\left(D_{2} \mid D_{d g}, D_{b}, D_{s f}, D_{i t}, D_{t l}, D_{s s}\right)\right] \\
& -C_{r}-C_{u}-C_{b} \\
& n_{g} \leq S
\end{aligned}
$$

Berdasarkan Persamaan (29), $\left(p^{*}\right),\left(n_{g^{*}}\right)$ dan $\left(m^{*}\right)$ merupakan variabel keputusan pada model beragam jenis.

Biaya ruangan untuk rak $\left(t_{0} m n_{g}^{2}\right)$ per item tidak termasuk dalam keuntungan pengusaha, akan tetapi tetap menjadi perhatian utama pada saat pengusaha memutuskan apakah suatu produk harus dijual di toko dan berapa banyak ruangan untuk rak penjualan. Oleh karena itu, total keuntungan yang diharapkan pengusaha tanpa memasukan biaya ruangan untuk rak adalah

$$
\begin{aligned}
E(\Pi)_{o p t}= & E\left[p f\left(D_{1} \mid D_{d g}, D_{b}, D_{s f}, D_{i t}, D_{t l}, D_{s s}\right)\right]+E\left[p \Theta f\left(D_{2} \mid D_{d g}, D_{b}, D_{s f}, D_{i t}, D_{t l}, D_{s s}\right)\right] \\
& -C_{u}-C_{b}
\end{aligned}
$$




\section{Optimasi Model Beragam Jenis}

Keuntungan $E(\Pi)$ dalam rantai pasok beragam jenis makanan tidak tahan lama dipengaruhi oleh dua kendala, seperti harga jual makanan $(p)$ dan besar ruangan untuk rak $\left(n_{g}\right)$. Derivatif fungsi $E(\Pi)$ orde kedua terhadap kendala ( $p$ ) dan $Q$ adalah sebagai berikut:

$$
\begin{aligned}
& \frac{\partial^{2} E(\Pi)}{\partial p^{2}}=-\frac{4 b}{t_{0}}-\frac{4 b \Theta^{2}\left(T-t_{0}\right)}{T^{2}-t_{0}{ }^{2}}>0 \\
& \frac{\partial^{2} E(\Pi)}{\partial n_{g}{ }^{2}}=-2 t_{0} m<0
\end{aligned}
$$

Syarat perlu untuk memaksimalkan $E(\pi)$ adalah $\frac{\partial E(\pi)}{\partial p}=\frac{\partial E(\pi)}{\partial n_{g}}=0$. Matriks simetri Hessian dari $E(\pi)$ adalah

$$
H=\left[\begin{array}{cc}
\frac{\partial^{2} E(\Pi)}{\partial p^{2}} & \frac{\partial^{2} E(\Pi)}{\partial p \partial n_{g}} \\
\frac{\partial^{2} E(\Pi)}{\partial n_{g} \partial p} & \frac{\partial^{2} E(\Pi)}{\partial n_{g}{ }^{2}}
\end{array}\right]=\left(-\frac{4 b}{t_{0}}-\frac{4 b \Theta^{2}\left(T-t_{0}\right)}{T^{2}-t_{0}^{2}}\right) \cdot\left(-2 t_{0} m\right)-\left(\frac{2 c}{t_{0}}\right)^{2}
$$

Dalam Persamaan (33), terdapat

sehingga

$$
\frac{\partial^{2} E(\Pi)}{\partial n_{g} \partial p}=\frac{\partial^{2} E(\Pi)}{\partial p \partial n_{g}}=\frac{2 c_{0}}{t_{0}}>0
$$

$$
H=\frac{4\left(2 \Theta^{2} b m t_{0}{ }^{3}+2 T b m t_{0}{ }^{2}+2 b m t_{0}{ }^{3}-T c^{2}-c^{2} t_{0}\right)}{\left(T-t_{0}\right) t_{0}{ }^{2}}<0
$$

Fungsi $E(\Pi)$ maksimal dengan kendala $\left(p^{*}\right)$ dan $\left(n_{g} *\right)$.

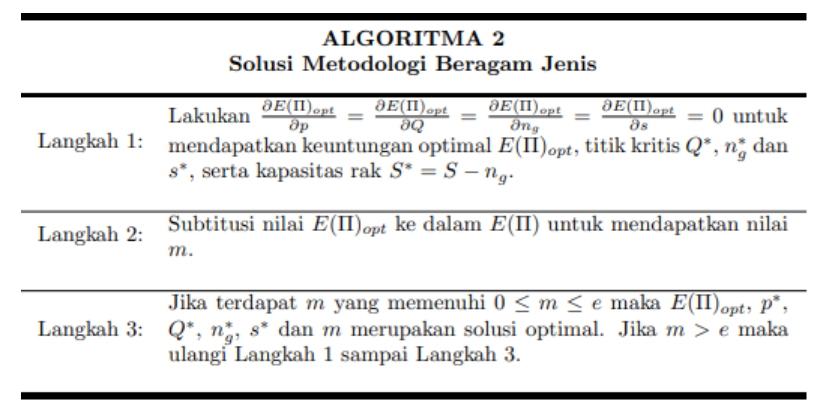

Gambar 2. Algoritma 2

Algoritma 2 merupakan solusi metodologi untuk menyelesaikan simulasi numerik makanan tidak tahan lama beragam jenis pada subbab selanjutnya.

\section{Simulasi Numerik}

Simulasi numerik dibagi dalam dua kasus yaitu Kasus I untuk model satu jenis dan Kasus II untuk model beragam jenis.

Kasus I. Gambar 3 di bawah ini menunjukkan parameter yang diperoleh dari Xiao (2016) yaitu:

\begin{tabular}{cccc}
\hline Parameter & Value & Parameter & Value \\
\hline$a$ & 30 & $q 0$ & 0.9 \\
$b$ & 1.8 & $\Theta$ & 0.65 \\
$c$ & 2 & $\lambda$ & 0.01 \\
$d ; r$ & 1.5 & $m$ & 0.9 \\
$h$ & 2 & $t_{0}$ & 10 \\
$T$ & 12 & $L$ & 10 \\
$C_{s}$ & $\$ 0.005$ & $C_{d}$ & $\$ 0.005$ \\
\hline
\end{tabular}

Gambar 3. Nilai parameter 
Efisiensi Rantai Pasok pada Makanan Tidak Tahan Lama Berdasarkan Permintaan Stokastik dan Densitas ...

Berikut simulasi numerik dari tingkat diskon, ketidakpastian permintaan konsumen, dan tingkat penurunan kualitas makanan tidak tahan lama dengan nilai-nilai input yang berbeda berdasar Algoritma 1.

Berikut nilai parameter dengan nilai rasio harga diskon yang berbeda:

\begin{tabular}{|c|c|c|c|c|c|c|c|}
\hline No & $\Theta$ & $\theta$ & $p^{*}$ & $Q^{*}$ & $s^{*}$ & $n_{G}^{*}$ & $E(\pi)_{\text {opt }}$ \\
\hline 1 & 0,60 & $40 \%$ & 9,153 & 1197788 & 104911 & 0,046 & $\$ 1.501 .459,95$ \\
2 & 0,61 & $39 \%$ & 9,149 & 1210360 & 105843 & 0,042 & $\$ 1.516 .215,62$ \\
3 & 0,62 & $38 \%$ & 9,145 & 1222092 & 106712 & 0,038 & $\$ 1.530 .104,23$ \\
4 & 0,63 & $37 \%$ & 9,141 & 1232989 & 107519 & 0,033 & $\$ 1.543 .128,01$ \\
5 & 0,64 & $36 \%$ & 9,136 & 1243054 & 108264 & 0,028 & $\$ 1.555 .289,30$ \\
6 & 0,65 & $35 \%$ & 9,131 & 1228053 & 107171 & 0,011 & $\$ 1.541 .030,39$ \\
\hline
\end{tabular}

Gambar 4. Solusi optimal dengan tingkat diskon yang berbeda

Gambar 4 menunjukkan bahwa ketika diskon yang diberikan menurun, maka harga dan ruangan untuk rak mengalami penurunan, serta jumlah pemesanan dan jumlah stok cenderung mengalami peningkatan. Selain hal tersebut, dalam Tabel 2 pengurangan diskon dapat meningkatkan permintaan konsumen terhadap makanan tidak tahan lama di rak diskon. Oleh karena itu, pengusaha dapat meningkatkan harga jual yang tidak terlalu tinggi dari harga beli untuk mendorong pendapatan yang lebih besar. Pada Tabel 2 didapat grafik sebagai berikut:

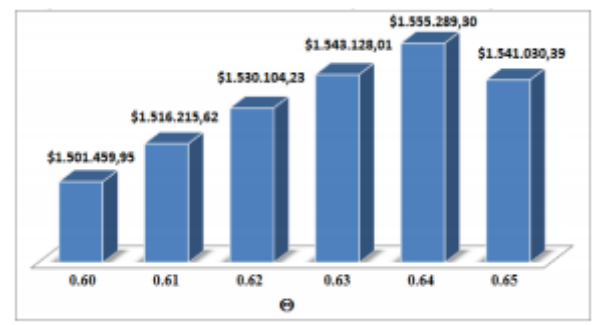

Gambar 5: Keuntungan optimal dengan tingkat diskon yang berbeda

Berdasarkan Gambar 5 dapat dilihat bahwa keuntungan optimal tampak cekung ke bawah dalam strategi diskon. Keuntungan optimalnya mencapai maksimumnya di sekitar tingkat diskon 0.64 atau pada diskon $36 \%$.

Ketidakpastian permintaan konsumen merupakan salah satu faktor terpenting yang dapat mempengaruhi keuntungan secara signifikan. Dengan menggunakan $(p *),(Q *),\left(n_{g}{ }^{*}\right)$ dan $(s *)$ yang didapatkan dari tingkat diskon 0.65 diperoleh

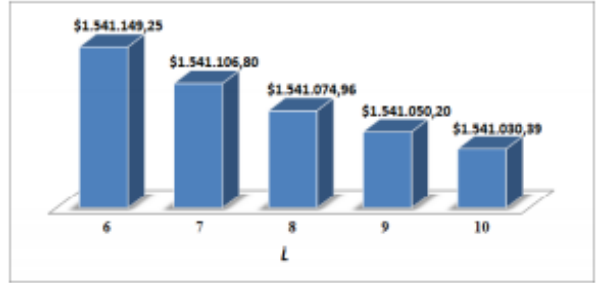

Gambar 6: Keuntungan optimal dengan (1) yang berbeda

Gambar 6 menunjukkan bahwa semakin rendah ketidakpastian permintaan konsumen terhadap makanan tidak tahan lama, maka semakin tinggi keuntungan optimal yang didapat oleh pengusaha. Efek dari fluktuasi permintaan konsumen tidak dapat dikurangi dengan menyesuaikan strategi penetapan harga dan diskon, kebijakan stok, serta ruangan untuk rak. Hal tersebut menunjukkan bahwa rantai pasok pada makanan tidak tahan lama sulit untuk dikelola. Dalam mengatasi hal tersebut, sebuah pasar berusaha mengecilkan efek dari fluktuasi permintaan konsumen secara berulang kali. Akibatnya, prediksi permintaan konsumen terhadap makanan tidak tahan lama dan strategi promosi yang fleksibel sangat penting dalam pengelolaan rantai pasok pada makanan tidak tahan lama. 
Dengan nilai parameter yang termuat dalam Tabel 1, dengan tingkat penurunan kualitas makanan tidak tahan lama berbeda, didapat

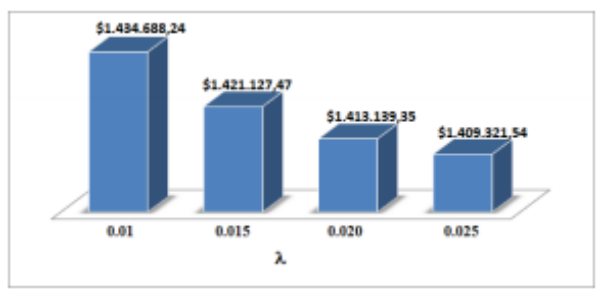

Gambar 7: Keuntungan maksimal dengan $(\lambda)$ yang berbeda

Gambar 7 menunjukkan bahwa dengan meningkatnya tingkat penurunan kualitas makanan atau tingkat kerusakan makanan, maka pengusaha memilih untuk mengurangi harga jual, ruangan untuk rak, jumlah pemesanan makanan di grosir dan mengurangi kebijakan stok di toko. Menurut (Yang, 2017) dalam kehidupan nyata, pengusaha industri makanan lebih memilih mempersingkat siklus pengisian ulang dan penyetokan makanan tidak tahan lama yang diakibatkan dari efek penurunan kualitas makanan. Namun, kedua tindakan pengusaha tersebut dapat mengakibatkan tingginya biaya operasional dan karena itu dapat mengurangi keuntungan di toko. Tingginya tingkat penurunan kualitas makanan tidak tahan lama menyebabkan sebagian besar makanan dijual pada siklus pengisian awal di toko. Hal tersebut menyebabkan pengusaha sering kehabisan stok dalam waktu yang singkat di toko. Bagi pengusaha industri makanan, teknologi pelacakan untuk tingkat penurunan kualitas makanan dan strategi promosi yang fleksibel dapat diterapkan untuk meningkatkan efisiensi rantai pasok pada makanan tidak tahan lama, serta dapat mengurangi limbah akibat pembusukan makanan.

Kasus II. (Xiao, 2016) menyatakan nilai parameter untuk model beragam jenis adalah sebagai berikut:

\begin{tabular}{cccc}
\hline Parameter & Value & Parameter & Value \\
\hline$a$ & $27 ; 30 ; 25 ; 30$ & $q 0$ & $0.9 ; 0.85 ; 1 ; 0.75$ \\
$b$ & $1.4 ; 1.8 ; 2 ; 1.5$ & $\Theta$ & $0.65 ; 0.75 ; 0.6 ; 0.85$ \\
$c$ & $1.8 ; 2 ; 1.5 ; 1.3$ & $\lambda$ & $0.005 ; 0.01 ; 0.012 ; 0.12$ \\
$d ; r$ & $1.2 ; 1.5 ; 1.6 ; 1$ & $e$ & 0.1 \\
$h$ & $3 ; 2 ; 2.5 ; 2$ & $t_{0}$ & $20 ; 10 ; 10 ; 8$ \\
$T$ & $24 ; 12 ; 12 ; 10$ & $\beta$ & $\$ 0.005 ; \$ 0.002 ; \$ 0.001 ; \$ 0.007$ \\
$S$ & 40 & $\alpha$ & $\$ 15 ; \$ 10 ; \$ 5 ; \$ 17$ \\
\hline
\end{tabular}

Gambar 8. Nilai parameter beragam jenis

Pada Gambar 8 akan dilakukan simulasi numerik beragam jenis yang dilandasi oleh Algoritma 2. Didapat

\begin{tabular}{|c|r|c|}
\hline Kapasitas $S^{*}$ & $m$ & $E(\Pi)_{o p t}$ \\
\hline 52 & $\$ 0,01$ & $\$ 10,49$ \\
47 & $\$ 0,02$ & $\$ 8,05$ \\
45 & $\$ 0,02$ & $\$ 6,33$ \\
44 & $\$ 0,03$ & $\$ 3,77$ \\
\hline
\end{tabular}

Gambar 9. Keuntungan optimal dengan kapasitas rak yang berbeda

Model beragam jenis makanan tidak tahan lama digunakan untuk mengevaluasi efek dari kapasitas ruang rak terhadap keuntungan optimal di toko. Kapasitas ruangan untuk rak merupakan salah satu faktor utama dalam memenuhi kepuasan pelanggan. Ruangan rak yang menarik dan memudahkan konsumen dalam mencari makanan yang dibutuhkan dapat meningkatkan kepuasan pelanggan saat berbelanja makanan tidak tahan lama di toko. Oleh karena itu, lingkungan berbelanja yang nyaman, produk penjualan yang beragam, dan harga jual yang murah akan lebih diminati oleh konsumen. Gambar 9 menunjukkan bahwa ketika kapasitas ruang rak meningkat, keuntungannya juga meningkat. Pada jenis makanan tidak tahan lama yang sama, pendapatan satu sama lainnya tetap meningkat secara eksponensial. Akibatnya penjual dapat menambahkan variasi makanan baru, sehingga dapat menambah keuntungan.

Toko yang berukuran luas dapat menggunakan ruangan untuk rak yang lebih besar, akan tetapi toko yang berukuran kecil mungkin memiliki keunggulan lain dibandingkan toko yang besar. Contohnya, 
rak yang berukuran kecil dan jenis makanan yang sedikit, dapat menyebabkan toko-toko kecil menyediakan layanan yang baik pada konsumen. Oleh karena itu, meningkatkan variasi produk mungkin bukan pilihan bagi penjual ketika rak yang lebih besar tersedia.

\section{PENUTUP}

\section{Kesimpulan}

Pengusaha dapat memperpendek siklus pengisian ulang dan stok makanan tidak tahan lama, serta teknologi pelacakan untuk penurunan kualitas makanan dan strategi promosi yang fleksibel dapat diterapkan di toko. Menurut hasil simulasi numerik dengan menggunakan densitas bersyarat, kapasitas rak yang lebih besar dapat meningkatkan keuntungan di toko. Toko yang berukuran luas dapat menggunakan kapasitas ruangan untuk rak yang lebih besar. Semakin besar kapasitas rak akan semakin murah biaya pembelian untuk rak. Selain biaya yang murah, dengan kapasitas rak yang lebih besar pengusaha dapat menambahkan variasi makanan baru, karena produk penjualan yang beragam akan lebih populer dan diminati oleh konsumen. Strategi penentuan harga dan diskon memiliki hubungan yang erat dengan tingkat penurunan kualitas makanan, keputusan dalam kebijakan stok dan penentuan besarnya ruangan untuk rak. Dalam simulasi numerik yang dilandasi permintaan stokastik menunjukan bahwa penetapan harga jual sebaiknya tidak terlalu tinggi dari harga beli pada grosir. Selain strategi harga jual, keuntungan optimal mencapai maksimum di sekitar diskon 36\% di dalam strategi penetapan diskon dengan dilandasi permintaan stokastik. Oleh karena itu, peningkatan efisiensi rantai pasok pada makanan tidak tahan lama berdasarkan permintaan stokastik dan densitas bersyarat dapat dilakukan dengan mengevaluasi secara kompeherensif strategi penetapan harga, ruangan untuk rak, kebijakan stok dan kebijakan pengisian ulang atau restock dengan didukung teknologi pelacakan tingkat penurunan kualitas makanan dan teknologi modern, seperti RFID dan sensor suhu kelembaban.

\section{Saran}

Jenis distribusi untuk permintaan konsumen yang bersifat stokastik dapat diasumsikan dengan distribusi normal atau distribusi Poisson. Kebijakan-kebijakan seperti kebijakan penetapan strategi harga dan diskon, serta kebijakan stok dapat dilanjutkan sebagai kasus, dengan menyelidiki makanan mulai dari suppliers atau pemasok sampai ke toko.

\section{REFERENSI}

Bukeviciute, Lina, Adriaan Dierx, and Fabienne Ilzkovitz, The functioning of the food supply chain and its effect on food prices in the European Union, Belgium: Directorate-General for Economic and Financial Affairs., 2009. http://dx.doi.org/10.2765/43477

B. Ling, J. Tang, F. Kong, E. J. Mitcham, and S. Wang, "Food and Bioprocess Technology: Kinetics of Food Quality Changes During Thermal Processing: a Review", An International Journal, 2015 http://dx.doi.org/10.1007/s11947-014-1398-3

Xiao, Yujie., and Shuai Yang, "The retail chain design for perishable food: The case of price strategy $\begin{array}{llll}\text { and shelf } \quad \text { space } & \text { allocation”, }\end{array}$ www.mdpi.com/journal/sustainability/10.3390/su9010012

Yang, Shuai, Yujie Xiao, and Yong-Hong Kuo, "The supply chain design for perishable food with stochastic demand", Sustainability, www.mdpi.com/journal/sustainability/10.3390/su9071195 